\title{
Evaluation of Verticillium Wilt Resistance in Mentha arvensis and M. longifolia Genotypes
}

Jeremiah K. S. Dung, Brenda K. Schroeder, and Dennis A. Johnson, Department of Plant Pathology, Washington State University, Pullman 99164-6430

\begin{abstract}
Dung, J. K. S., Schroeder, B. K., and Johnson, D. A. 2010. Evaluation of Verticillium wilt resistance in Mentha arvensis and M. longifolia genotypes. Plant Dis. 94:1255-1260.

Verticillium wilt, caused by Verticillium dahliae, is a major constraint to mint (Mentha spp.) production in the United States, and the use of resistant cultivars is an important component of Verticillium wilt management. Two Mentha arvensis and four M. longifolia genotypes were evaluated for resistance to Verticillium wilt in the greenhouse using $V$. dahliae isolates obtained from different hosts and belonging to different vegetative compatibility groups. Isolates of $V$. dahliae obtained from peppermint (M. × piperita) caused significantly higher disease severity, plant mortality, and yield reduction than isolates obtained from other hosts. Disease severity, plant mortality, and pathogen incidence in aboveground stems were higher and yields lower in peppermint, the susceptible standard, compared with the resistant standard, native spearmint $(M$. spicata). Root-dip inoculations of $M$. arvensis and M. longifolia with isolates of $V$. dahliae obtained from peppermint produced severe symptoms; however, both species displayed the ability to recover from infection and produce asymptomatic growth from rhizomes. Both M. arvensis cultivars exhibited lower mean disease severity ratings following cutback and regrowth and were not significantly different than native spearmint. The restriction of pathogen movement in aboveground tissue and ability to recover from infection may be important components of $V$. dahliae resistance in perennial mint cropping systems.
\end{abstract}

Verticillium wilt, caused by Verticillium dahliae Kleb., is a major disease affecting mint (Mentha L.) production in the United States. Symptoms of Verticillium wilt in mint can include anthocyanescence, bronzing or curling of the apical leaves, chlorosis, stunting, wilt, necrosis, and premature senescence (20). Losses occur due to decreased oil production and stand reduction, which can worsen over the lifetime of the perennial crop. Fields of peppermint $(M . \times$ piperita L.) and Scotch spearmint (M. × gracilis Sole) can be severely affected by Verticillium wilt while another commercially grown species, native spearmint $(M$. spicata $\mathrm{L}$.), is more resistant (5).

The host range of $V$. dahliae includes hundreds of dicotyledonous species in various genera $(1,9,40)$. Despite its broad host range, some isolates of $V$. dahliae exhibit varying degrees of aggressiveness on certain host species $(6,8)$. In addition,

Corresponding author: J. K. S. Dung

E-mail: dungj@wsu.edu

PPNS No. 0538, Department of Plant Pathology, College of Agricultural, Human, and Natural Resource Sciences Agricultural Research Center, Project No. WNP00678, Washington State University, Pullman 99164-6430.

Accepted for publication 28 June 2010.

doi:10.1094/PDIS-01-10-0062

(c) 2010 The American Phytopathological Society isolates can be separated into vegetative compatibility groups (VCGs) based on their ability to undergo hyphal anastomosis and form stable heterokaryons with other isolates $(9,23)$. Most $V$. dahliae isolates collected from mint belong to VCG $2 \mathrm{~B}$, are highly aggressive on mint, and can interact synergistically with the root lesion nematode Pratylenchus penetrans $(14,25)$, indicating the possible presence of a mint pathotype $(12,16,25)$.

Initial inoculum of $V$. dahliae consists primarily of soilborne microsclerotia, which form in senescing plants and can survive in soils for over 10 years $(18,32,40)$. Microsclerotia germinate in response to plant root exudates (33) and hyphae colonize the root surface and cortex. Verticillium wilt symptoms occur when the pathogen penetrates the stele and invades the xylem, where it is systemically translocated through the host vascular system (15). The pathogen is capable of colonizing the roots of resistant and nonhosts but it appears that the fungus is restricted from extensively colonizing the cortex and is unable to infiltrate the xylem $(2,3,15,45)$. Microsclerotia are produced at host senescence, and colonized plant debris can contribute to future inoculum levels if incorporated into soil. Conidia can also be produced during host senescence but do not survive as long as microsclerotia and are not known to play a significant role in the disease cycle $(18,45)$. Rhizomes used for planting may also be infected by $V$. dahliae, providing a potential source of primary inoculum in fields previously not planted to mint (30).

Verticillium wilt is managed primarily through the use of pathogen-free planting stock, rotations with nonsusceptible monocotyledonous crops, and preplant fumigation $(17,34)$. Environmental and economical concerns may limit the future use of chemical controls. Crop rotation is of only limited benefit, largely due to the ability of $V$. dahliae to colonize and survive on numerous hosts and nonhosts and its long persistence in soil. The development of resistant cultivars offers a promising tool to manage Verticillium wilt in other host systems $(11,27,44)$. Unfortunately, both peppermint and Scotch spearmint are sterile hybrids and conventional breeding is not possible. Mint mutants derived from irradiation treatment produced mixed results $(21,24,35,42)$; however, other characteristics such as plant vigor, oil composition, and yield are of critical importance during cultivar development and may not be retained using nonspecific mutation techniques (31). Recent advances in Agrobacterium tumefaciens-mediated transformation of peppermint offers the opportunity to introduce Verticillium wilt resistance genes from other Mentha spp. into sterile mint hybrids without altering desirable oil composition or quality characteristics $(36,46,50)$.

The genus Mentha includes at least 18 species, 11 hybrids, and numerous varieties (43), all of which are potential sources of Verticillium wilt resistance. Mentha arvensis $\mathrm{L}$. is the most widely grown mint in the world, and menthol derived from $M$. arvensis is used in a variety of cosmetics, foods, and tobacco products (10). India is now the leading producer of $M$. arvensis menthol, mostly due to the development and integration of an annual mint cropping system with existing food production systems, an efficient distilling infrastructure, and the development of high-yielding, disease-resistant cultivars $(4,28,29,41)$. A prior study investigated the impacts of powdery mildew (Erysiphe cichoracearum), rust (Puccinia menthae), and leaf spot (Alternaria alternata) on $M$. arvensis cultivars and genotypes (26); however, the potential effects of $V$. dahliae infection of $M$. arvensis are not known.

Another Mentha sp., M. longifolia (L.) L., is a wild relative of cultivated mint with a wide geographic range and a relatively 
high degree of intraspecific variation $(43,49)$. Verticillium wilt resistance-like sequences, similar to the tomato $V e$ gene effective against $V$. dahliae race $1(27,39)$, were previously identified in M. longifolia using degenerate polymerase chain reaction primers. Differences in Verticillium wilt response were also demonstrated in various genotypes of $M$. longifolia using a single $V$. dahliae isolate $(48,49)$. The objectives of this greenhouse study were to evaluate responses of $M$. arvensis cvs. Paraguayan and Shivalik and M. longifolia accessions CMEN 584 and CMEN 585 (previously described as susceptible and resistant to Verticillium wilt, respectively) using $V$. dahliae isolates from various hosts and VCGs. In addition, a single progeny from a cross of the resistant and susceptible $M$. longifolia accessions $\left(\mathrm{F}_{1}\right)$ and a single progeny from an $F_{1}$ self-cross $\left(F_{2}\right)$ were evaluated. Plants were inoculated using a root-dip method and Verticillium wilt symptoms, mortality, stem colonization, and yield were measured over successive croppings and compared with susceptible (M. $\times$ piperita 'Black Mitcham') and resistant (M. spicata) standards.

\section{MATERIALS AND METHODS}

Plant material and $V$. dahliae isolates. In total, five isolates of $V$. dahliae were used in the $M$. arvensis experiments. Isolates 109 and 111 (both VCG 2B) were both obtained from peppermint. Isolate 109 was previously demonstrated to be highly aggressive on $M . \times$ piperita Black Mitcham and $M . \times$ gracilis $(12,24)$. Isolate VSP 695, also VCG 2B, was obtained from spinach seed and kindly provided by L. du Toit (Washington State University NWREC, Mt. Vernon). Isolate 601 (VCG 4A) was obtained from cherry (Prunus sp.) and isolate 240 (VCG 4B) was obtained from potato (Solanum tuberosum L.). An additional isolate from potato, isolate 653 (VCG 4A), was also used in the M. longifolia experiments. All isolates used were obtained from hosts in Washington State. The identities of isolates were confirmed as $V$. dahliae using polymerase chain reaction and species-specific primers based on the $\beta$-tubulin 2 gene as described by Atallah et al. (2) Disease assays on M. arvensis cultivars were conducted independently of $M$. longifolia assays in separate greenhouse trials and both experiments were repeated. The first experiment consisted of two Mint Industry Research Council lines of $M$. arvensis, Paraguayan and Shivalik, while the second experiment consisted of M. longifolia United States Department of Agriculture accessions CMEN 584 (plant introduction [PI] 557769) and CMEN 585 (PI 557767), a single progeny from a CMEN $584 \times$ CMEN 585 cross (designated " $F_{1}$ "), and a single progeny from an $\mathrm{F}_{1}$ self-cross (designated " $\mathrm{F}_{2}$ "). $M$. arvensis cultivars were obtained from Summit Laboratories, Inc. (Fort Collins, CO) and
M. longifolia genotypes were obtained from Kelly Vining (University of New Hampshire, Durham). All experiments consisted of four replicates and included M. $\times$ piperita Black Mitcham and M. spicata as susceptible and resistant standards, respectively. Mint plants were vegetatively propagated by treating $7-$ to $10-\mathrm{cm}$ apical cuttings with Root-Tone $(0.20 \% \quad 1$ Naphthaleneacetamide and $4.04 \%$ tetramethylthiuram-disulfide; Black Leaf Products, Louisville, KY) and rooted in flats filled with Sunshine LC1 peat-based media (SunGro, Bellevue, WA) for 4 to 6 weeks.

Conidial suspensions of each $V$. dahliae isolate were prepared by inoculating 125 $\mathrm{ml}$ of Czapeks-Dox broth (MP Biomedicals, Solon, $\mathrm{OH}$ ) with $1-\mathrm{cm}^{2}$ plugs taken from single-spore isolates grown on potato dextrose agar (PDA). Liquid cultures were incubated on a 150 -rpm shaker at 22 to $23^{\circ} \mathrm{C}$ in the dark for 5 to 7 days. Conidia were strained through four layers of cheesecloth to remove mycelia. Conidial concentrations were quantified with a hemacytometer and adjusted to $1 \times 10^{6}$ conidia/ml by adding sterile distilled water $\left(\mathrm{sdH}_{2} \mathrm{O}\right)$. Rooted cuttings were uplifted and potting media gently rinsed from the roots prior to inoculation. Rooted cuttings were soaked for $5 \mathrm{~min}$ in $100 \mathrm{ml}$ of conidial suspension, with control inoculations consisting of a 5-min soak in $\mathrm{sdH}_{2} \mathrm{O}$. Plants were transplanted into $10-\mathrm{cm}^{2}$ pots (J. M. McConkey \& Co., Inc., Puyallup, WA,) filled with Sunshine LC1 media and arranged in a randomized complete block design. Natural light was supplemented to achieve a photoperiod of at least $15 \mathrm{~h}$ when necessary. Temperatures in the greenhouse during the $M$. arvensis experiments ranged diurnally from 8.6 to $25.6^{\circ} \mathrm{C}$ (trial 1) and 9.8 to $32.8^{\circ} \mathrm{C}$ (trial 2), while temperatures during the $M$. longifolia experiments ranged from 6.9 to $32.8^{\circ} \mathrm{C}$ (trial 1) and 9.4 to $32.8^{\circ} \mathrm{C}$ (trial 2).

Disease severity, stem assays, and yield measurements. Verticillium wilt symptoms were assessed approximately 4 weeks postinoculation (wpi) and weekly thereafter using the following disease severity index (DSI): $0=$ no visible symptoms; $1=$ mild chlorosis, $<10 \%$ of plant; 2 $=$ distinct chlorosis, 10 to $20 \%$ of plant; 3 $=$ asymmetrical apical growth, chlorosis 20 to $40 \%$ of plant, or stunting $(<80 \%$ height of control plants); $4=$ chlorosis on $>40 \%$ of plant, or severe stunting $(<60 \%$ height of control plants); $5=$ necrosis on $>40 \%$ of plant; and $6=$ dead or nearly dead plant. At 8 wpi, plants were cut at 1 to $2 \mathrm{~cm}$ above the soil line and allowed to regrow for an additional 8 weeks, at which point disease ratings were recorded and plants cut back again.

Stem assays were conducted following each 8-week growth period. Two 4-cm basal stem sections were arbitrarily sampled from each plant, surface sterilized in $0.5 \% \mathrm{NaOCl}$ for $3 \mathrm{~min}$, and plated onto
Whatman filter paper moistened with $\mathrm{sdH}_{2} \mathrm{O}$. Plates were incubated for 5 days in the dark and checked for $V$. dahliae conidiophores and microsclerotia formation. Identification was performed by microscopic examination of conidiophores, conidia, and microsclerotia and verified by subplating onto PDA when necessary. Following regrowth ratings and stem assays, the remaining aboveground tissue (stems, leaves, and flowers) was cut to 1 to $2 \mathrm{~cm}$ above the soil line and dried for 2 weeks, and the total mass (yield) was recorded. Yields were converted to yield ratios using the formula yield $\operatorname{ratio}_{n(x)}=$ yield $_{n(x)} /$ mean yield $\operatorname{control}(x)_{\text {, whe }} n(x)=$ individual yield observation of mint species $(x)$ and $\operatorname{control}(x)=$ the mean yield of the noninoculated mint species $(x)$ control treatment. A yield ratio $<1$ indicates a reduced yield compared with the mean yield of the noninoculated control treatment of the same mint genotype.

Data analysis. Areas under the disease progress curve (AUDPCs) were calculated for ratings taken during the first 8 weeks using the formula $\sum_{i}^{n-1}\left[\left(Y_{i}+Y_{i+1}\right) / 2\right]\left(t_{i+1}\right.$ $\left.-t_{i}\right)$, where $Y_{i}=$ cumulative disease severity at the $i$ th observation, $t_{i}=$ time (days postinoculation) at the $i$ th observation, and $n=$ number of observations. Analysis of variance (ANOVA) was performed using PROC GLM in SAS (version 9.1; SAS Institute, Cary, NC). AUDPC data, regrowth ratings, and yield ratios were analyzed separately, and comparisons were made between $V$. dahliae isolates and Mentha spp. using Tukey's honestly significant difference test at $P<0.05$.

\section{RESULTS}

M. arvensis trials. Root-dip inoculations of $M . \times$ piperita Black Mitcham and both $M$. arvensis cultivars with isolates 109 and 111, both obtained from peppermint, resulted in significantly higher AUDPC values than inoculations with other isolates in both trials (Table 1). Inoculations with isolate 240 caused significantly higher AUDPC values than waterinoculated controls for Paraguayan in both trials. Overall, Shivalik and M. spicata exhibited higher and lower AUDPC values, respectively, during the first 8-week growth period. $M . \times$ piperita Black Mitcham exhibited the highest DSI following regrowth in both trials (Table 1 ). Only $M$. $\times$ piperita Black Mitcham inoculated with isolates 109 and 111 exhibited significantly higher DSI ratings than waterinoculated controls following harvest and regrowth in both trials. There was considerable variation in DSI values among replicates of $M$. arvensis inoculated with isolates 109 and 111, with DSI values ranging between 0 (no symptoms) to 6 (dead plant). Only V. dahliae isolates 109 and 111 caused plant senescence and mortality was highest for $M . \times$ piperita Black Mitcham (Table 2). 
Yield ratios for $M . \times$ piperita Black Mitcham inoculated with isolate 111 were reduced significantly in both trials (Table 3). Isolate 109 caused a significant reduction in mean yield ratio in $M . \times$ piperita Black Mitcham during the first trial but mean yield reduction was not significant in the second trial. Although isolates obtained from other hosts sometimes resulted in higher or lower mean yield ratios than controls, these differences were not significant in either trial. Stem assays resulted in the recovery of $V$. dahliae predominantly from plants inoculated with isolates obtained from mint, and assays of $M . \times$ piperita Black Mitcham plants inoculated with isolates 109 and 111 resulted in the recovery of the pathogen from $100 \%$ of stems (Table 2).

M. longifolia trials. Consistent with both $M$. arvensis trials, isolates 109 and 111, both obtained from peppermint, caused significantly higher AUDPC values than all other isolates for all six mint lines tested in both M. longifolia trials (Table 4). The resistant standard M. spicata exhibited significantly lower overall AUDPC values than all other mint lines following inoculations with isolates 109 and 111 in both trials. Isolate 111 , obtained from peppermint, caused significantly higher DSI values than water-inoculated controls following regrowth for all mint lines except for M. spicata in both trials (Table 4). Isolate 109 caused significant DSI values following regrowth in $M . \times$ piperita Black Mitcham, CMEN 584, and $F_{1}$ in both trials. As with $M$. arvensis, DSI values ranging between 0 and 6 were observed following regrowth of $M$. longifolia replicates inoculated with peppermint isolates 109 and 111. Senescence (a disease rating of 6) only occurred in plants inoculated with these isolates obtained from peppermint; however, differences in plant mortality were not significant (Table 2).

Yield ratios were significantly reduced for $M . \times$ piperita Black Mitcham, CMEN 584 , and $\mathrm{F}_{1}$ by isolates 109 and 111 in both trials (Table 3). Isolate 111 also significantly reduced mean yield ratios for $F_{2}$ in both trials. Other significant reductions in mean yield ratio were observed but were not consistent among trials. Higher yield ratios were observed in CMEN 585 inoculated with isolates from other hosts in both trials. Stem assays recovered the pathogen primarily in plants inoculated with isolates 109 and 111 (Table 2). Pathogen recovery was relatively low for CMEN 585 and $M$. spicata in both trials.

\section{DISCUSSION}

Approximately 3 to 4 weeks following root-dip inoculation, observable differences in resistance were evident among mint cultivars as well as aggressiveness among the $V$. dahliae isolates. Inoculations of mint lines with both $V$. dahliae isolates obtained from peppermint often resulted in complete wilt, necrosis, and senescence of the inoculated stem by the conclusion of the first 8-week growth period. The exception was $M$. spicata, which exhibited only mild chlorosis and crescent leaf symptoms and only on rare occasions. Isolates obtained from hosts other than peppermint (VSP 695, 240, 601, and 653) were able to cause mild symptoms in all mint lines, including slight to moderate chlorosis and mild stunting or asymmetric apical growth. However, symptoms caused by isolates obtained from non-mint hosts were not as severe as those caused by isolates obtained from peppermint, and necrosis or plant mortality due to Verticillium wilt was not observed. Overall, isolates 109 and 111, both obtained from peppermint, produced

Table 2. Incidences of plant mortality and Verticillium dahliae recovery from aboveground stems of mint plants inoculated with isolates from peppermint ${ }^{\mathrm{Z}}$

\begin{tabular}{|c|c|c|c|c|c|c|}
\hline \multirow[b]{3}{*}{ Mint } & \multicolumn{6}{|c|}{ Incidence (\%) } \\
\hline & \multicolumn{3}{|c|}{ Isolate 109} & \multicolumn{3}{|c|}{ Isolate 111} \\
\hline & Mortality & Trial 1 & Trial 2 & Mortality & Trial 1 & Trial 2 \\
\hline \multicolumn{7}{|l|}{ Experiment 1} \\
\hline Black Mitcham & 30 & $100 \mathrm{a}$ & $100 \mathrm{a}$ & 50 & $100 \mathrm{a}$ & $100 \mathrm{a}$ \\
\hline Shivalik & 0 & $19 \mathrm{~b}$ & $13 \mathrm{~b}$ & 10 & $6 \mathrm{~b}$ & $29 \mathrm{~b}$ \\
\hline Paraguayan & 0 & $6 \mathrm{~b}$ & $13 \mathrm{~b}$ & 10 & $19 \mathrm{~b}$ & $7 \mathrm{~b}$ \\
\hline Mentha spicata & 0 & $0 \mathrm{~b}$ & $0 \mathrm{~b}$ & 0 & $0 \mathrm{~b}$ & $13 \mathrm{~b}$ \\
\hline \multicolumn{7}{|l|}{ Experiment 2} \\
\hline Black Mitcham & 30 & $100 \mathrm{a}$ & $94 \mathrm{a}$ & 30 & $100 \mathrm{a}$ & $94 \mathrm{a}$ \\
\hline M. longifolia 584 & 30 & $58 \mathrm{ab}$ & $69 \mathrm{ab}$ & 30 & $67 \mathrm{ab}$ & $86 \mathrm{ab}$ \\
\hline M. longifolia 585 & 40 & $17 \mathrm{bc}$ & $14 \mathrm{c}$ & 50 & $13 \mathrm{c}$ & $6 \mathrm{~d}$ \\
\hline $584 \times 585\left(\mathrm{~F}_{1}\right)$ & 30 & $58 \mathrm{ab}$ & $79 a$ & 30 & $64 \mathrm{ab}$ & $50 \mathrm{bc}$ \\
\hline $\mathrm{F}_{1} \times \mathrm{F}_{1}\left(\mathrm{~F}_{2}\right)$ & 30 & $21 \mathrm{bc}$ & $79 \mathrm{a}$ & 50 & $25 \mathrm{bc}$ & $60 \mathrm{ab}$ \\
\hline M. spicata & 0 & $0 \mathrm{c}$ & $31 \mathrm{bc}$ & 0 & $13 \mathrm{c}$ & $13 \mathrm{~cd}$ \\
\hline
\end{tabular}

z Mortality values indicate the total percentage of plants with a disease rating of 6 (dead or nearly dead plant) by the end of both trials. Values within a column followed by the same letter are not significantly different within trials using Tukey's test at $P=0.05$.

Table 1. Mean area under disease progress curve (AUDPC) and disease severity index (DSI) ratings of 'Black Mitcham' peppermint (susceptible), Mentha spicata (resistant), and two Mentha arvensis cultivars (Shivalik and Paraguayan) following root-dip inoculation with Verticillium dahliae isolates from different hosts and vegetative compatibility groups $(\mathrm{VCGs})^{\mathrm{z}}$

\begin{tabular}{|c|c|c|c|c|c|c|c|c|c|c|}
\hline \multirow[b]{5}{*}{ Rating, mint } & \multicolumn{10}{|c|}{ V. dahliae isolates } \\
\hline & \multicolumn{6}{|c|}{ VCG 2B } & \multirow{2}{*}{\multicolumn{2}{|c|}{$\begin{array}{c}\text { VCG 4A } \\
\text { Cherry } \\
\end{array}$}} & \multirow{2}{*}{\multicolumn{2}{|c|}{$\begin{array}{c}\text { VCG 4B } \\
\text { Potato }\end{array}$}} \\
\hline & \multicolumn{4}{|c|}{ Peppermint } & \multirow{2}{*}{\multicolumn{2}{|c|}{$\begin{array}{c}\text { Spinach } \\
695\end{array}$}} & & & & \\
\hline & \multicolumn{2}{|c|}{109} & \multicolumn{2}{|c|}{111} & & & \multicolumn{2}{|c|}{601} & \multicolumn{2}{|c|}{240} \\
\hline & Trial 1 & Trial 2 & Trial 1 & Trial 2 & Trial 1 & Trial 2 & Trial 1 & Trial 2 & Trial 1 & Trial 2 \\
\hline \multicolumn{11}{|l|}{ AUDPC } \\
\hline Black Mitcham & $85 \mathrm{a}^{*}$ & $80 \mathrm{ab}^{*}$ & $62 b^{*}$ & $77 b^{*}$ & $19 \mathrm{a}$ & $17 \mathrm{a}$ & $22 \mathrm{ab}$ & $9 \mathrm{a}$ & $16 \mathrm{a}$ & $9 \mathrm{a}$ \\
\hline Shivalik & $100 a^{*}$ & $95 \mathrm{a}^{*}$ & $95 \mathrm{a}^{*}$ & $104 a^{*}$ & $15 \mathrm{a}$ & $13 \mathrm{a}$ & $11 \mathrm{~b}$ & $8 \mathrm{a}$ & $15 \mathrm{a}$ & $23 a^{*}$ \\
\hline Paraguayan & 57 b* & $68 \mathrm{~b}^{*}$ & $68 \mathrm{ab}^{*}$ & $84 \mathrm{ab}^{*}$ & $17 \mathrm{a}$ & $23 \mathrm{a}^{*}$ & $32 \mathrm{a}^{*}$ & $15 \mathrm{a}$ & $25 \mathrm{a}^{*}$ & $24 \mathrm{a}^{*}$ \\
\hline M. spicata & $51 \mathrm{~b}^{*}$ & $21 c^{*}$ & $43 \mathrm{~b}^{*}$ & $23 c^{*}$ & $17 \mathrm{a}$ & $24 a^{*}$ & $9 \mathrm{~b}$ & $7 \mathrm{a}$ & $17 \mathrm{a}$ & $8 \mathrm{a}$ \\
\hline \multicolumn{11}{|l|}{ DSI } \\
\hline Black Mitcham & $1.7 a^{*}$ & $1.8 \mathrm{a}^{*}$ & $2.0 \mathrm{a}^{*}$ & $1.8 \mathrm{a}^{*}$ & $0.8 \mathrm{a}^{*}$ & $0.0 \mathrm{~b}$ & $0.9 \mathrm{a}^{*}$ & $0.0 \mathrm{a}$ & $1.0 \mathrm{a}^{*}$ & $0.0 \mathrm{a}$ \\
\hline Shivalik & $1.0 \mathrm{~b}^{*}$ & $0.8 \mathrm{~b}$ & $0.8 \mathrm{~b}^{*}$ & $0.5 \mathrm{ab}$ & $0.5 \mathrm{a}$ & $0.0 \mathrm{~b}$ & $0.7 \mathrm{a}$ & $0.0 \mathrm{a}$ & $0.5 \mathrm{ab}$ & $0.0 \mathrm{a}$ \\
\hline Paraguayan & $0.6 \mathrm{~b}$ & $0.6 \mathrm{~b}$ & $1.0 \mathrm{~b}^{*}$ & $0.9 \mathrm{ab}$ & $0.8 \mathrm{a}$ & $0.5 \mathrm{a}$ & $0.4 \mathrm{a}$ & $0.4 \mathrm{a}$ & $0.2 \mathrm{~b}$ & $0.5 \mathrm{a}$ \\
\hline M. spicata & $0.7 b^{*}$ & $0.2 \mathrm{~b}$ & $0.8 \mathrm{~b}^{*}$ & $0.2 \mathrm{~b}$ & $0.5 \mathrm{a}$ & $0.2 \mathrm{ab}$ & $0.4 \mathrm{a}$ & $0.0 \mathrm{a}$ & $0.5 \mathrm{ab}$ & $0.2 \mathrm{a}$ \\
\hline
\end{tabular}

${ }^{\mathrm{z}}$ Disease severity index (DSI): $0=$ no visible symptoms; $1=$ mild chlorosis, $<10 \%$ of plant; $2=$ distinct chlorosis, 10 to $20 \%$ of plant; $3=$ asymmetrical apical growth, chlorosis on 20 to $40 \%$ of plant, or stunting $(<80 \%$ height of control plants); $4=$ chlorosis on $>40 \%$ of plant or severe stunting ( $<60 \%$ height of control plants); $5=$ necrosis on $>40 \%$ of plant; and $6=$ dead or nearly dead plant. Values within a column followed by the same letter are not significantly different within trials using Tukey's test at $P=0.05$; * indicates a significant difference from water-inoculated controls within mints using Tukey's test at $P=0.05$. Plants were harvested at 8 weeks postinoculation and allowed to grow for an additional 8 weeks prior to disease severity index ratings. DSI ratings were $\log _{\mathrm{e}}$-transformed for analysis. 
significantly higher AUDPC $(P<0.0001)$ and DSI ratings following regrowth $(P<$ $0.0001)$ than isolates from other hosts in all four trials (Tables 1 and 4). Waterinoculated control plants did not exhibit any Verticillium wilt symptoms. Some variation in AUDPC values was observed between $M$. arvensis trials, particularly in $M$. spicata plants inoculated with isolates obtained from peppermint. The exact cause of the trial variability is not known but the timing of experiments may have played a role. AUDPC values for the first M. arvensis trial were recorded during July and August, whereas AUDPC readings for the second $M$. arvensis trial were recorded between March and May. Although the greenhouse environment is regulated, differences in diurnal temperature fluctuations or the amount and intensity of solar irradiation may have influenced the interaction between these isolates and $M$. spicata, impacting disease development.

Although $V$. dahliae generally exhibits a wide host range, some studies demonstrated variation in pathogen-host interactions among $V$. dahliae isolates and the presence of host-adapted populations capable of causing more severe symptoms on certain hosts $(6,38)$. Correlations between aggressiveness and VCG have been found to exist in some cases (37) and most $V$. dahliae isolates collected from peppermint belong to VCG $2 \mathrm{~B}$ and exhibit increased aggressiveness on peppermint (12). In this study, root-dip inoculations of $M$. × piperita Black Mitcham and all genotypes of $M$. arvensis and $M$. longifolia with $V$. dahliae isolates from peppermint resulted in significantly higher disease severity than inoculations with isolates obtained from other hosts, including a VCG 2B isolate collected from spinach seed. These results support previous studies suggesting that $V$. dahliae isolates collected from mint may be a host-adapted group within VCG $2 \mathrm{~B}$ $(6,12,16)$ and suggest that knowledge of both host origin and VCG are important in

Table 3. Mean yield ratios of 'Black Mitcham' peppermint (susceptible), Mentha spicata (resistant), two Mentha arvensis cultivars, and four Mentha longifolia genotypes following inoculation with Verticillium dahliae isolates from various hosts and vegetative compatibility groups (VCGs), harvest and regrowth ${ }^{\mathrm{Z}}$

\begin{tabular}{|c|c|c|c|c|c|c|c|c|c|c|c|c|}
\hline \multirow[b]{5}{*}{ Mint } & \multicolumn{12}{|c|}{ V. dahliae isolates } \\
\hline & \multicolumn{6}{|c|}{ VCG 2B } & \multicolumn{4}{|c|}{ VCG 4A } & \multirow{2}{*}{\multicolumn{2}{|c|}{$\begin{array}{c}\text { VCG 4B } \\
\text { Potato } \\
\end{array}$}} \\
\hline & \multicolumn{4}{|c|}{ Peppermint } & \multirow{2}{*}{\multicolumn{2}{|c|}{$\begin{array}{c}\text { Spinach } \\
695\end{array}$}} & \multirow{2}{*}{\multicolumn{2}{|c|}{$\begin{array}{c}\text { Cherry } \\
601\end{array}$}} & \multirow{2}{*}{\multicolumn{2}{|c|}{$\begin{array}{c}\text { Potato } \\
653\end{array}$}} & & \\
\hline & \multicolumn{2}{|c|}{109} & \multicolumn{2}{|c|}{111} & & & & & & & & \\
\hline & Trial 1 & Trial 2 & Trial 1 & Trial 2 & Trial 1 & Trial 2 & Trial 1 & Trial 2 & Trial 1 & Trial 2 & Trial 1 & Trial 2 \\
\hline \multicolumn{13}{|l|}{ Experiment 1} \\
\hline Black Mitcham & $0.4 \mathrm{a}$ & $0.3 b^{*}$ & $0.0 \mathrm{c}$ & $0.4 b^{*}$ & $1.1 \mathrm{a}^{*}$ & $1.2 \mathrm{a}$ & $1.6 \mathrm{a}^{*}$ & $0.9 \mathrm{a}$ & $\mathrm{Nt}$ & $\mathrm{Nt}$ & $1.4 \mathrm{a}^{*}$ & $0.9 \mathrm{a}$ \\
\hline Shivalik & $0.9 \mathrm{a}$ & $0.5 \mathrm{~b}$ & $1.1 \mathrm{a}$ & $0.4 \mathrm{~b}$ & $1.4 \mathrm{a}$ & $1.2 \mathrm{a}$ & $0.9 \mathrm{a}$ & $1.1 \mathrm{a}$ & $\mathrm{Nt}$ & $\mathrm{Nt}$ & $1.3 \mathrm{a}$ & $0.9 \mathrm{a}$ \\
\hline Paraguayan & $0.8 \mathrm{a}$ & $1.0 \mathrm{a}$ & $0.6 \mathrm{~b}$ & $0.5 \mathrm{ab}$ & $0.8 \mathrm{a}$ & $0.9 \mathrm{a}$ & $0.8 \mathrm{a}$ & $1.1 \mathrm{a}$ & $\mathrm{Nt}$ & $\mathrm{Nt}$ & $0.8 \mathrm{a}$ & $1.0 \mathrm{a}$ \\
\hline M. spicata & $1.0 \mathrm{a}$ & $1.1 \mathrm{a}$ & $0.9 \mathrm{ab}$ & $1.1 \mathrm{a}$ & $0.9 \mathrm{a}$ & $1.1 \mathrm{a}$ & $1.0 \mathrm{a}$ & $1.0 \mathrm{a}$ & $\mathrm{Nt}$ & $\mathrm{Nt}$ & $1.0 \mathrm{a}$ & $0.9 \mathrm{a}$ \\
\hline \multicolumn{13}{|l|}{ Experiment 2} \\
\hline Black Mitcham & $0.2 a^{*}$ & $0.3 b^{*}$ & $0.1 b^{*}$ & $0.3 \mathrm{~b}^{*}$ & $0.7 \mathrm{a}$ & $1.1 \mathrm{a}$ & $1.1 \mathrm{ab}$ & $1.0 \mathrm{~b}$ & $0.8 \mathrm{a}$ & $1.2 \mathrm{a}$ & $1.0 \mathrm{ab}$ & $1.2 \mathrm{a}$ \\
\hline M. longifolia 584 & $0.1 \mathrm{a}^{*}$ & $0.2 b^{*}$ & $0.1 \mathrm{~b}^{*}$ & $0.3 b^{*}$ & $0.7 \mathrm{a}$ & $1.2 \mathrm{a}$ & $0.8 \mathrm{~b}$ & $1.0 \mathrm{~b}$ & $0.7 \mathrm{a}$ & $1.2 \mathrm{a}$ & $0.8 \mathrm{~b}$ & $1.0 \mathrm{a}$ \\
\hline M. longifolia 585 & $0.5 \mathrm{a}$ & $0.9 \mathrm{ab}$ & $0.0 b^{*}$ & $1.2 \mathrm{a}$ & $1.2 \mathrm{a}$ & $1.1 \mathrm{a}$ & $1.4 \mathrm{a}^{*}$ & $1.1 \mathrm{ab}$ & $1.4 \mathrm{a}^{*}$ & $1.3 \mathrm{a}$ & $1.5 \mathrm{a}^{*}$ & $1.1 \mathrm{a}$ \\
\hline $584 \times 585\left(\mathrm{~F}_{1}\right)$ & $0.3 a^{*}$ & $0.2 b^{*}$ & $0.3 \mathrm{ab}^{*}$ & $0.4 b^{*}$ & $0.8 \mathrm{a}$ & $0.9 \mathrm{a}$ & $0.9 \mathrm{~b}$ & $1.0 \mathrm{~b}$ & $1.1 \mathrm{a}$ & $1.0 \mathrm{a}$ & $0.8 \mathrm{~b}$ & $1.0 \mathrm{a}$ \\
\hline $\mathrm{F}_{1} \times \mathrm{F}_{1}\left(\mathrm{~F}_{2}\right)$ & $0.5 \mathrm{a}$ & $0.5 \mathrm{ab}$ & $0.2 b^{*}$ & $0.4 \mathrm{~b}^{*}$ & $0.9 \mathrm{a}$ & $1.0 \mathrm{a}$ & $0.8 \mathrm{~b}$ & $1.1 \mathrm{ab}$ & $1.1 \mathrm{a}$ & $1.1 \mathrm{a}$ & $0.9 \mathrm{~b}$ & $1.1 \mathrm{a}$ \\
\hline M. spicata & $0.7 a^{*}$ & $1.1 \mathrm{a}$ & $0.7 \mathrm{a}$ & $1.2 \mathrm{a}$ & $0.7 \mathrm{a}$ & $1.1 \mathrm{a}$ & $1.0 \mathrm{~b}$ & $1.2 \mathrm{a}^{*}$ & $0.7 \mathrm{a}$ & $1.2 \mathrm{a}$ & $0.8 \mathrm{~b}$ & $1.2 \mathrm{a}$ \\
\hline
\end{tabular}

z Values within a column followed by the same letter are not significantly different within trials using Tukey's test at $P=0.05$; * indicates a significant difference from water-inoculated controls within mints using Tukey's test at $P=0.05 ; \mathrm{Nt}=$ not tested. Plants were cut back at 8 weeks postinoculation and allowed to grow for an additional 8 weeks prior to yield ratio measurements.

Table 4. Mean area under disease progress curve (AUDPC) and disease severity index (DSI) ratings of 'Black Mitcham' peppermint (susceptible), Mentha spicata (resistant), and four Mentha longifolia genotypes following root-dip inoculation with Verticillium dahliae isolates from different hosts and vegetative compatibility groups $(\mathrm{VCGs})^{\mathrm{z}}$

\begin{tabular}{|c|c|c|c|c|c|c|c|c|c|c|c|c|}
\hline \multirow[b]{5}{*}{ Mint } & \multicolumn{12}{|c|}{ V. dahliae isolates } \\
\hline & \multicolumn{6}{|c|}{ VCG 2B } & \multicolumn{4}{|c|}{ VCG 4A } & \multirow{2}{*}{\multicolumn{2}{|c|}{$\begin{array}{c}\text { VCG 4B } \\
\text { Potato } \\
\end{array}$}} \\
\hline & \multicolumn{4}{|c|}{ Peppermint } & \multirow{2}{*}{\multicolumn{2}{|c|}{$\begin{array}{c}\text { Spinach } \\
695\end{array}$}} & \multirow{2}{*}{\multicolumn{2}{|c|}{$\begin{array}{c}\text { Cherry } \\
601\end{array}$}} & \multirow{2}{*}{\multicolumn{2}{|c|}{$\begin{array}{c}\text { Potato } \\
653\end{array}$}} & & \\
\hline & \multicolumn{2}{|c|}{109} & \multicolumn{2}{|c|}{111} & & & & & & & & \\
\hline & Trial 1 & Trial 2 & Trial 1 & Trial 2 & Trial 1 & Trial 2 & Trial 1 & Trial 2 & Trial 1 & Trial 2 & Trial 1 & Trial 2 \\
\hline \multicolumn{13}{|l|}{ AUDPC } \\
\hline Black Mitcham & $70 b^{*}$ & $100 a^{*}$ & $70 \mathrm{bc}^{*}$ & $98 \mathrm{a}^{*}$ & $3 \mathrm{a}$ & $16 \mathrm{a}^{*}$ & $2 \mathrm{a}$ & $10 \mathrm{a}$ & $16 \mathrm{ab}$ & $18 \mathrm{a}^{*}$ & $10 \mathrm{a}$ & $28 \mathrm{a}^{*}$ \\
\hline M. longifolia 584 & $113 a^{*}$ & $110 a^{*}$ & $102 a^{*}$ & $109 a^{*}$ & $16 \mathrm{a}$ & $11 \mathrm{a}$ & $21 \mathrm{a}$ & $14 \mathrm{a}$ & $18 \mathrm{a}$ & $11 \mathrm{a}$ & $10 \mathrm{a}$ & $14 \mathrm{a}$ \\
\hline M. longifolia 585 & $83 a b^{*}$ & $64 \mathrm{~b}^{*}$ & $84 \mathrm{ab}^{*}$ & $68 b^{*}$ & $12 \mathrm{a}$ & $15 \mathrm{a}$ & $11 \mathrm{a}$ & $17 \mathrm{a}$ & $1 \mathrm{~b}$ & $25 \mathrm{a}$ & $5 \mathrm{a}$ & $17 \mathrm{a}$ \\
\hline $584 \times 585\left(\mathrm{~F}_{1}\right)$ & $111 \mathrm{a}^{*}$ & $107 \mathrm{a}^{*}$ & $104 \mathrm{a}^{*}$ & $96 \mathrm{a}^{*}$ & $7 \mathrm{a}$ & $12 \mathrm{a}$ & $8 \mathrm{a}$ & $16 \mathrm{a}$ & $6 a b$ & $12 \mathrm{a}$ & $7 \mathrm{a}$ & $28 \mathrm{a}^{*}$ \\
\hline $\mathrm{F}_{1} \times \mathrm{F}_{1}\left(\mathrm{~F}_{2}\right)$ & $84 a b^{*}$ & $97 \mathrm{a}^{*}$ & $92 \mathrm{ab}^{*}$ & $109 \mathrm{a}^{*}$ & $9 \mathrm{a}$ & $14 \mathrm{a}$ & $9 \mathrm{a}$ & $14 \mathrm{a}$ & $3 a b$ & $14 \mathrm{a}$ & $7 \mathrm{a}$ & $32 \mathrm{a}^{*}$ \\
\hline M. spicata & $36 \mathrm{c}^{*}$ & $37 b^{*}$ & $46 c^{*}$ & $34 \mathrm{c}^{*}$ & $10 \mathrm{a}$ & $12 \mathrm{a}$ & $2 \mathrm{a}$ & $13 \mathrm{a}$ & $8 \mathrm{ab}$ & $19 \mathrm{a}^{*}$ & $2 \mathrm{a}$ & $19 \mathrm{a}^{*}$ \\
\hline \multicolumn{13}{|l|}{ DSI } \\
\hline Black Mitcham & $1.8 \mathrm{a} *$ & $1.8 \mathrm{a}^{*}$ & $1.9 \mathrm{a}^{*}$ & $1.8 \mathrm{a}^{*}$ & $0.0 \mathrm{a}$ & $0.0 \mathrm{a}$ & $0.2 \mathrm{a}$ & $0.0 \mathrm{~b}$ & $0.2 \mathrm{a}$ & $0.0 \mathrm{a}$ & $0.0 \mathrm{a}$ & $0.0 \mathrm{a}$ \\
\hline M. longifolia 584 & $1.7 \mathrm{a}^{*}$ & $1.6 \mathrm{a}^{*}$ & $1.8 \mathrm{a}^{*}$ & $1.6 \mathrm{ab}^{*}$ & $0.0 \mathrm{a}$ & $0.2 \mathrm{a}$ & $0.0 \mathrm{a}$ & $0.0 \mathrm{~b}$ & $0.2 \mathrm{a}$ & $0.0 \mathrm{a}$ & $0.2 \mathrm{a}$ & $0.2 \mathrm{a}$ \\
\hline M. longifolia 585 & $1.0 \mathrm{a}$ & $1.1 \mathrm{ab}^{*}$ & $2.0 \mathrm{a}^{*}$ & $1.1 \mathrm{~b}^{*}$ & $0.2 \mathrm{a}$ & $0.4 \mathrm{a}$ & $0.4 \mathrm{a}$ & $0.0 \mathrm{~b}$ & $0.2 \mathrm{a}$ & $0.2 \mathrm{a}$ & $0.0 \mathrm{a}$ & $0.4 \mathrm{a}$ \\
\hline $584 \times 585\left(\mathrm{~F}_{1}\right)$ & $1.2 \mathrm{a}^{*}$ & $1.6 \mathrm{a}^{*}$ & $1.7 \mathrm{a}^{*}$ & $1.4 \mathrm{ab}^{*}$ & $0.0 \mathrm{a}$ & $0.2 \mathrm{a}$ & $0.0 \mathrm{a}$ & $0.5 \mathrm{a}$ & $0.2 \mathrm{a}$ & $0.4 \mathrm{a}$ & $0.5 \mathrm{a}$ & $0.7 \mathrm{a}^{*}$ \\
\hline $\mathrm{F}_{1} \times \mathrm{F}_{1}\left(\mathrm{~F}_{2}\right)$ & $1.0 \mathrm{a}$ & $1.6 \mathrm{a}^{*}$ & $1.3 \mathrm{a}^{*}$ & $1.6 \mathrm{ab}^{*}$ & $0.0 \mathrm{a}$ & $0.4 \mathrm{a}$ & $0.2 \mathrm{a}$ & $0.2 \mathrm{ab}$ & $0.2 \mathrm{a}$ & $0.4 \mathrm{a}$ & $0.2 \mathrm{a}$ & $0.5 \mathrm{a}$ \\
\hline M. spicata & $0.4 \mathrm{a}$ & $0.5 \mathrm{~b}$ & $0.4 \mathrm{~b}$ & $0.2 \mathrm{c}$ & $0.4 \mathrm{a}$ & $0.0 \mathrm{a}$ & $0.4 \mathrm{a}$ & $0.0 \mathrm{~b}$ & $0.2 \mathrm{a}$ & $0.2 \mathrm{a}$ & $0.6 \mathrm{a}$ & $0.4 \mathrm{a}$ \\
\hline
\end{tabular}

${ }^{\mathrm{z}}$ Disease severity index (DSI): $0=$ no visible symptoms; $1=$ mild chlorosis, $<10 \%$ of plant; $2=$ distinct chlorosis, 10 to $20 \%$ of plant; $3=$ asymmetrical apical growth, chlorosis on 20 to $40 \%$ of plant, or stunting ( $<80 \%$ height of control plants); $4=$ chlorosis on $>40 \%$ of plant or severe stunting $(<60 \%$ height of control plants); $5=$ necrosis on $>40 \%$ of plant; and $6=$ dead or nearly dead plant. Values within a column followed by the same letter are not significantly different within trials using Tukey's test at $P=0.05$; * indicates a significant difference from water-inoculated controls within mints using Tukey's test at $P=0.05$. Plants were harvested at 8 weeks postinoculation and allowed to grow for an additional 8 weeks prior to disease severity index ratings. DSI ratings were $\log _{\mathrm{e}}$-transformed for analysis. 
predicting the aggressiveness of a certain isolate on a given host species, and mint in particular. The presence of $V$. dahliae populations with different VCGs, each potentially containing subpopulations with varying degrees of aggressiveness, may complicate efforts to manage and quantify the pathogen in field soils. In addition, results from this study demonstrate that isolates collected from $M . \times$ piperita are capable of causing disease symptoms in two other mint species: $M$. arvensis, the most widely cultivated Mentha sp. in the world, and $M$. longifolia, a wild mint species with a global distribution.

In addition to differences in isolate aggressiveness, variation in disease resistance among Mentha spp. was evident. Disease severity, plant mortality, and pathogen isolation frequencies were higher and yield ratio lower in the susceptible standard $M . \times$ piperita Black Mitcham compared with the resistant standard $M$. spicata. Although root-dip inoculations of $M$. arvensis and $M$. longifolia genotypes with peppermint isolates of $V$. dahliae resulted in AUDPC values similar to or higher than $M . \times$ piperita Black Mitcham at 8 wpi, $M$. arvensis and $M$. longifolia genotypes exhibited a range of symptoms following cutback and regrowth, ranging from 0 (no symptoms) to 6 (dead plant), whereas $96 \%$ of $M . \times$ piperita Black Mitcham plants exhibited moderate to severe symptoms (DSI $\geq 4$ ) at the completion of all trials. The reasons for the observed variation in disease severity and plant mortality among replications of $M$. arvensis and $M$. longifolia are not known; however, the inherent rhizomatous and stoloniferous growth of Mentha spp. may allow plants to recover from initial infection, particularly if the rate of pathogen colonization is restricted or host growth is vigorous. Incorporating inoculum in the soil may help reduce this variation by constantly challenging the plant with the pathogen as new rhizomes and stolons grow and root through the soil.

Yields were consistently reduced only for M. × piperita Black Mitcham plants inoculated with $V$. dahliae isolates obtained from peppermint, most likely due to its high susceptibility and rate of mortality compared with the resistant standard $M$. spicata. Both $M$. arvensis cultivars exhibited relatively high yield ratios and low mortality rates compared with the standards in response to inoculation with $V$. dahliae isolates 109 and 111. Yield ratios for Shivalik inoculated with isolates 109 and 111 were considerably higher during the first trial compared with the second trial (Table 3). These differences may be related to small differences in initial plant size or variation in greenhouse conditions over the 24-week study. Among $M$. longifolia genotypes, $M$. longifolia CMEN 584 exhibited the lowest yield ratios and $M$. longifolia CMEN 585 the highest; how- ever, CMEN 585 also exhibited the highest mortality rate, especially during the first trial.

Differences in frequencies of pathogen isolations from stems were also evident among cultivars (Table 3). The pathogen was isolated from nearly $100 \%$ of stems collected from the susceptible standard $M$. $\times$ piperita Black Mitcham and less than $10 \%$ of stems collected from the resistant standard M. spicata. Pathogen reisolation from aboveground stems was relatively low $(<15 \%)$ in both $M$. arvensis cultivars compared with the other mint lines tested. Among $M$. longifolia genotypes, the pathogen was isolated in highest numbers from M. longifolia CMEN 584 and in lowest numbers from $M$. longifolia CMEN 585. As with symptoms and yield ratio, differences in environmental conditions or initial plant size may have contributed to interactions among some cultivars and isolates (Table 2), allowing some plants to recover and grow asymptomatically after initial infection.

Results from this study are consistent with a previous assessment by Vining et al. (49), in which $14 \mathrm{M}$. longifolia accessions were inoculated with a $V$. dahliae isolate from mint using a similar root-dip procedure. They identified CMEN 584 and CMEN 585 as susceptible and resistant $M$. longifolia genotypes, respectively. Vining et al. $(47,48)$ sequenced $m V e 1$, a putative homolog of the dominant Verticillium wilt resistance (Ve) gene which confers $V$. dahliae race 1 resistance in tomato, in $M$. longifolia CMEN 585. Verticillium wilt resistance screenings of several $F_{1}$ and $F_{2}$ $M$. longifolia populations suggested that genes other than $m V e 1$ are involved in Verticillium wilt-resistant $M$. longifolia genotypes (47). Results from experiments using peppermint plants transformed with $V e$-like sequences cloned from $M$. longifolia CMEN 585 also suggest that other genes may be involved (13). In this study, the genotype tested from the $\mathrm{F}_{1}$ generation of a CMEN $584 \times$ CMEN 585 cross exhibited a lower mortality rate than CMEN 585; however, it exhibited reduced yield ratios, higher disease severity, and a higher incidence of pathogen reisolation from aboveground stems compared with CMEN 585. Interestingly, although CMEN 585 consistently exhibited lower DSI ratings and pathogen isolation rates and higher yield ratios than $M$. longifolia CMEN 584, it also exhibited one of the highest mortality rates among all mint lines evaluated. Reduced symptoms, restricted pathogen colonization, sustained yield, and low mortality would all be desirable traits in a Verticillium wilt-resistant mint cultivar.

The identification of resistant phenotypes is a necessary first step in the process of resistant cultivar development. Previous studies on Verticillium wilt resistance in lettuce, potato, and other crops have suggested that host suppression of cortex colonization, stele penetration, and xylem invasion are important components of resistant phenotypes $(15,19,22,45)$. Data from this study are consistent with prior studies demonstrating differences in pathogen incidence within stems of resistant and susceptible mint species $(7,20)$, suggesting that resistance in mint may involve the prevention of vascular or aboveground colonization by the pathogen. Results from this study demonstrate that $M$. arvensis and $M$. longifolia possess the ability to recover from severe $V$. dahliae infection and produce asymptomatic shoots from belowground rhizomes. This may be especially important in mint, considering the rhizomatous and stoloniferous nature of the crop, which may allow the plant to escape from pathogen foci in soil and establish new plants in noninfested areas. The ability to restrict aboveground stem colonization may not only reduce symptoms and yield loss during the current growing season but also could provide a long-term impact by reducing the accumulation of $V$. dahliae-infested debris in the soil. Mint is grown as a perennial in the United States, and the restriction of $V$. dahliae colonization in aboveground stems observed in the Mentha spp. tested may be especially significant because repeated harvests present multiple opportunities for infested debris to become incorporated into field soils.

\section{ACKNOWLEDGMENTS}

We thank the Mint Industry Research Council and the Washington Mint Commission for funding this project and $\mathrm{T}$. Cummings and J. Ingram for laboratory, greenhouse and statistical assistance.

\section{LITERATURE CITED}

1. Agrios, G. N. 1997. Plant Pathology. Academic Press, San Diego.

2. Atallah, Z. K., Bae, J., Jansky, S. H., Rouse, D. I., and Stevenson, W. R. 2007. Multiplex realtime quantitative PCR to detect and quantify Verticillium dahliae colonization in potato lines that differ in response to Verticillium wilt. Phytopathology 97:865-872.

3. Bae, J., Atallah, Z. K., Jansky, S. H., Rouse, D. I., and Stevenson, W. R. 2007. Colonization dynamics and spatial progression of Verticillium dahliae in individual stems of two potato cultivars with differing responses to potato early dying. Plant Dis. 91:1137-1141.

4. Bahl, J. R., Bansal, R. P., and Kumar, S. 2002. Direct planting of the short-duration summer crop using cold stored suckers of menthol mint Mentha arvensis. J. Hortic. Sci. Biotechnol. 77:217-219.

5. Berry, S. Z., and Thomas, C. A. 1961. Influence of soil temperature, isolates, and method of inoculation on resistance of mint to Verticillium wilt. Phytopathology 51:169-174.

6. Bhat, R. G., and Subbarao, K. V. 1999. Host range specificity in Verticillium dahliae. Phytopathology 89:1218-1225.

7. Brandt, W. H., Lacy, M. L., and Horner, C. E. 1984. Distribution of Verticillium in stems of resistant and susceptible species of mint. Phytopathology 74:587-591.

8. Chang, R. J., and Eastburn, D. M. 1994. Host range of Verticillium dahliae from horseradish and pathogenicity of strains. Plant Dis. 78:503506.

9. Chen, W. 1994. Vegetative compatibility 
groups of Verticillium dahliae from ornamental woody plants. Phytopathology 84:214-219.

10. Clark, G. S. 2007. Aroma chemical profile: menthol. Perfumer Flavorist 32:38-47.

11. Colella, C., Miacola, C., Amenduni, M., D'Amico, M., Bubici, G., and Cirulli, M. 2008. Sources of Verticillium wilt resistance in wild olive germplasm from the Mediterranean region. Plant Pathol. 57:533-539.

12. Douhan, L. I., and Johnson, D. A. 2001. Vegetative compatibility and pathogenicity of Verticillium dahliae from spearmint and peppermint. Plant Dis. 85:297-302.

13. Dung, J. 2009. Evaluation of Verticillium Wilt resistance in transgenic Mentha $\times$ piperita "Black Mitcham" expressing Ve-like sequences from M. longifolia. M.S. thesis, Washington State University, Pullman.

14. Faulkner, L. R., and Skotland, C. B. 1965. Interactions of Verticillium dahliae and Pratylenchus minyus in Verticillium wilt of peppermint. Phytopathology 55:583-586.

15. Fradin, E. F., and Thomma, B. P. H. J. 2006. Physiology and molecular aspects of Verticillium wilt diseases caused by $V$. dahliae and $V$. albo-atrum. Mol. Plant Pathol. 7:71-86.

16. Green, R. J. 1951. Studies on the host range of the Verticillium that causes wilt of Mentha piperita L. Science 113:207-208.

17. Green, R. J. 1967. Control of Verticillium wilt of peppermint by crop rotation sequences. Plant Dis. Rep. 51:441-453.

18. Green, R. J. 1969. Survival and inoculum potential of conidia and microsclerotia of Verticillium albo-atrum in soil. Phytopathology 59:874-876.

19. Griffiths, D. A. 1971. The development of lignitubers in roots after infection by Verticillium dahliae Kleb. Can. J. Microbiol. 17:441-444.

20. Horner, C. E. 1954. Pathogenicity of Verticillium isolates to peppermint. Phytopathology 44:239-242.

21. Horner, C. E., and Melouk, H. A. 1977. Screening, selection, and evaluation of irradiation-induced mutants of spearmint for resistance to Verticillium wilt. Int. Atomic Energy Agency SM:214/20:253-262.

22. Huisman, O. C. 1988. Seasonal colonization of roots of field-grown cotton by Verticillium dahliae and $V$. tricorpus. Phytopathology 78:708-716.

23. Joaquim, T. R., and Rowe, R. C. 1990. Reassessment of vegetative compatibility relationships among strains of Verticillium dahliae using nitrate-nonutilizing mutants. Phytopathology 80:1160-1166.

24. Johnson, D. A., and Cummings, T. F. 2000. Evaluation of mint mutants, hybrids, and fertile clones for resistance to Verticillium dahliae. Plant Dis. 84:235-238.

25. Johnson, D. A., and Santo, G. S. 2001. Devel- opment of wilt in mint in response to infection by two pathotypes of Verticillium dahliae and co-infection by Pratylenchus penetrans. Plant Dis. 85:1189-1192.

26. Kalra, A., Singh, H. B., Patra, N. K., Pandey, R., Shukla, R. S., and Kumar, S. 2001. The effect of leaf spot, rust and powdery mildew on yield components of nine Japanese mint (Mentha arvensis) genotypes. J. Hortic. Sci. Biotechnol. 76:546-548.

27. Kawchuk, L. M., Hachey, J., Lynch, D. R., Kulcsar, F., van Rooijen, G., Waterer, D. R., Robertson, A., Kokko, E., Byers, R., Howard, R. J., Fischer, R., and Prufer, D. 2001. Tomato $V e$ disease resistance genes encode cell surface-like receptors. Proc. Natl. Acad. Sci. U.S.A. 98:6511-6515.

28. Kumar, S., Bahl, J. R., Bansal, R. P., Gupta, A. K., Singh, V., and Sharma, S. 2002. High economic returns from companion and relay cropping of bread wheat and menthol mint in the winter-summer season in north Indian plains. Ind. Crops Prod. 15:103-114.

29. Kumar, S., Bahl, J. R., Shukla, P., Singh, A., Ram, G., Bansal, R. P., and Sharma, S. 1999. Screening of genotypes of menthol mint Mentha arvensis for high yields of herbage and essential oil under late cropping conditions of the sub-tropical Indo-Gangetic plains. J. Hortic. Sci. Biotechnol. 74:680-684.

30. Lacy, M. L., and Horner, C. E. 1966. Behavior of Verticillium dahliae in the rhizosphere and on roots of plants susceptible, resistant, and immune to wilt. Phytopathology 56:427-430.

31. Lawrence, B. M. 2007. The composition of commercially important mints. Pages 217-323 in: Mint: The Genus Mentha. B. M. Lawrence, ed. CRC Press, Boca Raton, FL.

32. Menzies, J. D., and Griebel, G. E. 1967. Survival and saprophytic growth of Verticillium dahliae in uncropped soil. Phytopathology 57:703-709.

33. Mol, L. 1995. Effect of plant roots on the germination of microsclerotia of Verticillium dahliae. Eur. J. Plant Pathol. 101:679-685.

34. Morrell, A., Schreiber, A., and Lundy, R. 1997. Pests, pest control, and fertilizer use in Washington mint. Rep. No. MISC0188. Washington State University Cooperative Extension, Pullman.

35. Murray, M. J., and Todd, W. A. 1972. Registration of Todd's Mitcham peppermint. Crop Sci. 12:128.

36. Niu, X., Li, X., Veronese, P., Bressan, R. A., Weller, S. C., and Hasegawa, P. M. 2000. Factors affecting Agrobacterium tumefaciensmediated transformation of peppermint. Plant Cell Rep. 19:304-310.

37. Omer, M. A., Johnson, D. A., and Rowe, R. C. 2000. Recovery of Verticillium dahliae from North American certified seed potatoes and characterization of strains by vegetative compatibility and aggressiveness. Am. J. Potato Res. 77:325-331.

38. Qin, Q. M., Vallad, G. E., Wu, B. M., and Subbarao, K. V. 2006. Phylogenetic analyses of phytopathogenic isolates of Verticillium spp. Phytopathology 96:582-592.

39. Schaible, L., Cannon, O. S., and Waddoups, B. 1951. Inheritance of resistance to Verticillium wilt in a tomato cross. Phytopathology 41:986990.

40. Schnathorst, W. C. 1981. Life cycle and epidemiology of Verticillium. Pages 81-111 in: Fungal Wilt Diseases of Plants. M. E. Mace, A A. Bell, and C. H. Beckman, eds. Academic Press, New York.

41. Singh, A. K., Srivastava, R. K., Kalra, A. Bansal, R. P., Tomar, V. K. S., Bahl, J. R., and Kumar, S. 2003. New practices in the cultivation of the mint, Mentha arvensis in the IndoGangetic plains. Exp. Agric. 39:199-207.

42. Todd, W. A., Green, R. J., and Horner, C. E. 1977. Registration of Murray Mitcham peppermint. Crop Sci. 17:188

43. Tucker, A. O., and Naczi, R. F. C. 2007. Men tha: an overview of its classification and relationships. Pages 1-39 in: Mint: The Genus Mentha. B. M. Lawrence, ed. CRC Press, Boca Raton, FL.

44. Vallad, G. E., Qin, Q. M., Grube, R., Hayes, R. J., and Subbarao, K. V. 2006. Characterization of race-specific interactions among isolates of Verticillium dahliae pathogenic on lettuce. Phytopathology 96:1380-1387.

45. Vallad, G. E., and Subbarao, K. V. 2008. Colonization of resistant and susceptible lettuce cultivars by a green fluorescent protein-tagged isolate of Verticillium dahliae. Phytopathology 98:871-885.

46. Veronese, P., Li, X., Niu, X., Weller, S. C Bressan, R. A., and Hasegawa, P. M. 2001 Bioengineering mint crop improvement. Plant Cell Tiss. Org. Cult. 64:133-144.

47. Vining, K., and Davis, T. 2009. Isolation of a Ve homolog, $m V e 1$, and its relationship to Verticillium wilt resistance in Mentha longifolia (L.) Huds. Mol. Genet. Genomics 282:173 184.

48. Vining, K. J., Zhang, Q., Smith, C. A., and Davis, T. M. 2007. Identification of resistance gene analogs and Verticillium wilt resistancelike sequences in Mentha longifolia. J. Am. Soc. Hortic. Sci. 132:541-550.

49. Vining, K. J., Zhang, Q., Tucker, A. O., Smith, C., and Davis, T. M. 2005. Mentha longifolia (L.) L.: a model species for mint genetic research. HortScience 40:1225-1229.

50. Wildung, M. R., and Croteau, R. B. 2005 Genetic engineering of peppermint for improved essential oil composition and yield. Transgenic Res. 14:365-372. 